\title{
QUALITY ANALYSIS OF SUPPORT MARKETING AND QUALITY OF SALES TRAINING ON SALES PERFORMANCE CAPABILITY ON PERFORMANCE SALES PERFORMANCE
} (Empirical Case on BNI Channel Direct Sales Credit Card Sales Team Semarang and Yogyakarta)

Ria Mawar Hapsari ${ }^{1}$

Farida Indriani ${ }^{2}$

Sutopo ${ }^{3}$

1,2,3 Master of Management, Faculty of Economics and Business, Diponegoro University

\begin{abstract}
This study aims to analyze and examine the effect of quality marketing support, sales quality, sales force capability to salespeople performance, with the formulation of the problem of "how to improve sales force performance" on channel Direct Sales Credit Card at BNI Semarang and Yogyakarta Regional Office.

Populations and samples selected in the study were credit card sales BNI channel Direct Sales Semarang and Yogyakarta, which amounted to 110 respondents, with the census method. Data collection using questionnaire with answer value 1 (very strongly disagree) up to 10 (very strongly agree).

Data analysis using Structural Equation Modeling (SEM) through AMOS program, with result indicate that research model acceptable, goodness of fit index as follows: Chi Square =126,774; Probability $=0.177 ;$ RMSEA $=0.033 ; \mathrm{GFI}=$ $0.885 ; \mathrm{AGFI}=0.845 ; \mathrm{TLI}=0.984$; and $\mathrm{CFI}=0.987$.

The conclusions of this study indicate that sales force capability can affect salesperson performance by looking at the quality of marketing support. This study also shows that sales force capability can affect salesperson performance by looking at the quality of sales training.
\end{abstract}

Keywords: Quality Marketing Support, Quality Sales Force Training, Salesperson Capability, Salesperson Performance. 


\section{INTRODUCTION}

The banking industry in recent years has been growing rapidly, giving rise to a very tight banking competition climate. In order to survive in the face of competition, bank players need to focus on innovation and improvement in terms of service, related to products to be offered to customers in the form of ease of service, differentiation and launch of new products with development and innovation through the features of banking products that have been provided. In the competition climate, what becomes interesting is when the products offered by the banking industry in Indonesia tend to be the same. With the similarity of these products, to win the competition, the perpetrators of the banking industry must continue to create and have more value than other banks. Two more values that should be owned by the banking industry and can be differentiated than other banks is a service/customer service and a reliable sales team. Service is when the customer comes to the Bank for the purposes of the transaction, either open an account, ask the product, complaint / complain or perform other bank transactions, the bank is obliged to serve well in accordance with or even exceed the expectation of its customers, as well as when customers interact with the bank through other channels (non walk-in channel) if the customer is satisfied / more than expected, that is the success of the service. While the sales team has a very important task because the sales force is one of the spearheads is very familiar with the intended market company. To provide maximum profit and sales increase, the target will be given to every salesperson in their company. As the direction/purpose of corporate profits and to achieve these targets, it takes creativity and carefulness of the sales force in capturing every opportunity that exists in the surrounding environment.

The capability of a good sales force needs to be supported by the quality of good marketing support from the organization and the quality of sales training provided, the better the salesperson's capability the salesperson's performance will increase. Increased sales force capability needs to be supported by the quality of marketing support and good sales training quality in order to be able to encourage the capability of the sales force to improve its performance.

The problem that arose in this research has described the performance of credit card from credit card sales team BNI channel Direct Sales Semarang and Yogyakarta in 2014 to 2015 has decreased significantly to $35 \%$, whereas in the year 2016 there was an increase of $21 \%$ from the year 2015. Increase in performance in 2016 has not been compared with the performance in 2014. If viewed the data table above, the acquisition from 2014 to 2016 is still not consistent. This is allegedly due to the lack of optimal performance of salespeople. Total sales performance in BNI Semarang area is also inconsistent from month to 
month, high turnover of sales force also become one cause of inconsistent performance of credit card BNI from the year 2014 until 2016. From the discussion can be drawn out the problem that is how to improve performance sales force channel Direct Sales Credit Card at BNI Semarang and Yogyakarta Regional Offices.

The purpose of this research is to:

1. Analyze and know the effect of quality marketing support on sales force capability.

2. Analyze and know the effect of quality marketing support on salesperson performance

3. Analyze and know the effect of quality sales training on sales force capability.

4. Analyze and know the effect of quality sales training on salesperson performance.

5. Analyze and know the influence of sales force capability on salesperson performance.

\section{LITERATURE REVIEW}

Performance is an indication of the success of a person indicating that his work has been completed properly and on time in accordance with the standards set. Baldauf et al. (2001) in his research revealed that the performance of salespeople is a result of sales force participation in achieving corporate goals. The company sets out the steps that salespeople need to perform to generate targeted sales force performance. Sales performance can be obtained from aggressiveness and accuracy in serving its customers (Spiro \& Weitz, 1990). Indicators of work are sales volume, customer growth and sales growth (Ferdinand, 2002).

Sales performance is an improvement achieved by salespeople and sales organizations, where it is seen as a character owned by salespeople that reflect hard work and smart working to achieve organizational goals (Churchil et al., 1997). Salespeople need to conduct self-management in their sales activities well in order to achieve effective performance (Kahn et al., 1990). In addition, the success rate of a salesperson in the business world cannot be separated from the ability of a salesperson in establishing good relationships with other companies (Curtis et al., 2000).

Based on the description above, sales force performance is the spearhead of the marketing process that started from the channeling of credit, making promo program, collectability, and profit generated from interest and administration. Sujan 
et al. (1988) conveyed about innovative marketing behaviors capable of improving sales productivity.

Barker (1999) measures the performance of salespeople through the ability to dominate the market, increase the number of sales, and achieve high corporate profits from the acquisition of the market. Badger et al. (2000) state that a salesperson needs to have expertise that is able to understand the relationship between the company and the customer in forming a strategy implementation that benefits both parties. Based on this, a salesperson must participate positively to achieve the target so that the company can generate high profits. Baldauf et al. (2001) show that sales force capability has a positive effect on salesperson performance. Crosby et al. (1990) state the important attributes of a salesperson is the expertise of salespeople in conducting sales activities. Rehme and Rennhak (2011) show that high competition environments support salespeople in achieving good performance.

Here is the hypothesis that can be drawn from the above exposure:

H1: The quality of marketing support has a positive effect on the capability of the sales force

H2: The quality of marketing support has a positive effect on salesperson performance

Effective sales training is done in a continuous way by the company, in the hope that salespeople can improve their skills and skills in sales activities (Indriani, 2005). Pettijohn (1994) points out that sales training is a core factor in the success of a personal selling. Many of the benefits of sales training are to overcome the problems and failures that will occur, improve the timing and the region, increase the morale, increase productivity, improve good relations with customers and reduce employee turnover.

In a marketing flow, salespeople should be able to provide satisfaction to customers by being able to meet what the customer needs. Salespeople have an important role in the sales process, so it takes experience in selling, in addition to the sales force is also required to maintain good relationships with customers, providing good maintenance as well so that will certainly be useful later on. Thus in order to survive, salespeople should always be ready for the tough competition and accept all the changes that exist in the marketing world (Massey and Dawes, 2007).

Asiegbu et al. (2012) said that the quality of sales training has an important role to give birth to a reliable sales force, has a high learning spirit and thirst for science that will make salespeople become someone who is expert in their field. Training is fundamental for every salesperson to follow, with their training to be 
educated on how to improve performance, have a sales strategy, and have responsibility for meeting the targets given to each salesperson so that this is an important thing for each career improvement -an employee (Smith, 2004). Training is also needed to lure creative things in a salesperson so that it can give birth to different strategies that can be utilized for the achievement of their performance (Verbeke et al., 2008).

Abdurrahmat (2006) states that effectiveness can be done by maximizing the available sources, costs, and infrastructure as appropriate so that work can be completed on time. The timely completion of work is able to lead to a focused sales force activity, consistent with its process flow as an important role of sales force performance capability (Piercy et al., 1997).

The results of Suff and Reilly (2012) show that sales quality sales variables have a strong influence on salesperson performance. The higher the capability of the sales forces the higher the performance of power sales. The quality of sales training can add to the science so that salespeople become more expert in their fields and generate salesperson performance (Asiegbu et al., 2012).

Galante et al. (2016) shows that salespeople are the first individual factors to introduce a company's product to its customers, a salesperson with good capability is very much in control of the target market in relation to the needs of its customers, because it requires a sales training that integrated from the company to improve the capability of a salesperson. The relationship between these two variables is very strong, where with the quality of good sales training then the salesperson can improve the capability.

Salespeople need good capability or capability to achieve their performance. Organizations need to provide training in stages and conducted regularly to improve their ability given the high competence of salespeople, with the existence of quality training so that salespeople increasingly mastering the work it is able to improve its ability. The above explanation generates the following hypothesis:

H3: The quality of sales training has a positive effect on the capability of the sales force

Roman et al. (2012) in his research using several factors such as sales training, customer orientation, salesperson performance, and sales force effectiveness. The result is that sales training can develop the science and capability of the sales force so that it can grow what is called the salesperson's performance.

Galante et al. (2016) suggests that salespeople are the first individual factors to introduce a company's product to its customers, a salesperson with good 
performance strongly in the market to which it is related to the needs of its customers, as it requires a sales training that integrated from the company to improve the performance of a salesperson. The relationship between the two variables is very strong, where with the quality of good sales training then the salesperson can improve its performance.

The salesperson needs to reach the target charged by reaching the job target. The organization needs to provide training in stages and conducted regularly to improve its performance given the high competence of the sales force, with the quality of training so that salespeople increasingly mastering the work it is able to improve its performance. The above explanation generates the following hypothesis:

H4: The quality of sales training has a positive effect on salesperson performance.

Salespeople need to have good ability to achieve high performance. The organization needs to improve the ability of the sales force through training and marketing support to improve its performance given the high competence of the sales force, with the quality of training so that salespeople increasingly master the work, this is able to improve its performance. The above explanation generates the following hypothesis:

H5: Salesforce capability has a positive effect on salesperson performance

Here are the results of previous research that became a reference for this study.

Table 1

Previous Research

\begin{tabular}{|c|c|c|c|c|}
\hline No & Researchers & Variable Research & Analyzer & Research result \\
\hline 1 & $\begin{array}{l}\text { Ahmad et al. } \\
(2010)\end{array}$ & $\begin{array}{l}\text { Quality of marketing } \\
\text { support, sales force } \\
\text { capability, and performance } \\
\text { of sales force }\end{array}$ & SEM & $\begin{array}{l}\text { Quality of marketing } \\
\text { support able to influence } \\
\text { salesperson capability } \\
\text { and salesperson } \\
\text { performance }\end{array}$ \\
\hline 2 & $\begin{array}{l}\text { Rehme and } \\
\text { Rennhak } \\
(2011)\end{array}$ & $\begin{array}{l}\text { Quality marketing support, } \\
\text { sales force capability, and } \\
\text { sales force performance }\end{array}$ & SEM & $\begin{array}{l}\text { Quality marketing } \\
\text { support able to influence } \\
\text { salesperson } \\
\text { performance }\end{array}$ \\
\hline 3 & $\begin{array}{l}\text { Verbeke et } \\
\text { al. (2011) }\end{array}$ & $\begin{array}{l}\text { Quality of sales training, } \\
\text { sales force capability, } \\
\text { performance of salespeople }\end{array}$ & SEM & $\begin{array}{l}\text { The quality of sales } \\
\text { training can affect the } \\
\text { performance of } \\
\text { salespeople }\end{array}$ \\
\hline
\end{tabular}




\begin{tabular}{cllcl}
\hline No & Researchers & \multicolumn{1}{c}{ Variable Research } & Analyzer & \multicolumn{1}{c}{ Research result } \\
\hline 4 & $\begin{array}{l}\text { Asiegbu et } \\
\text { al. (2012) }\end{array}$ & $\begin{array}{l}\text { Quality of sales training, } \\
\text { sales force capability, and } \\
\text { sales force performance }\end{array}$ & SEM & $\begin{array}{l}\text { Quality sales training } \\
\text { can affect salesperson } \\
\text { performance }\end{array}$ \\
\hline
\end{tabular}

Source: Various Journals (2016)

Based on the literature review, the following conclusions can be put forth in the picture below:

Figure 1

\section{Theoretical Framework}

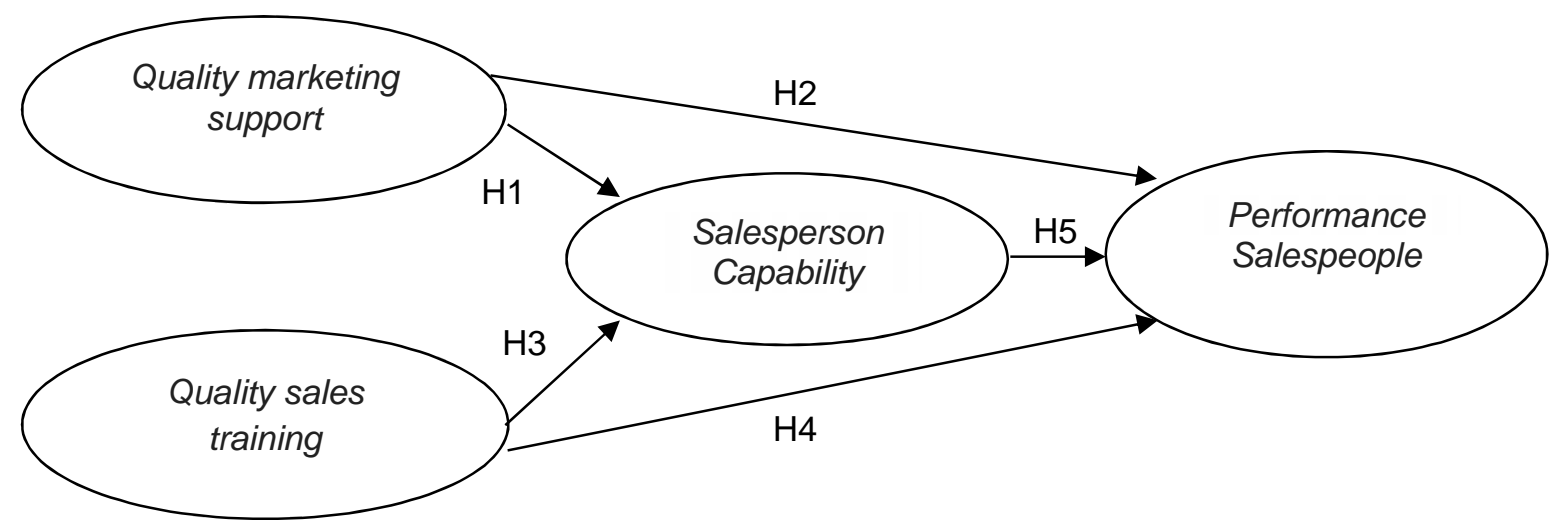

Sources: developed for this study, (2017)

Dimensionalized variables and conceptual definitions can be explained in the following table:

Table 2

Dimensionalized Variables and Conceptual Definitions

\begin{tabular}{|c|c|c|c|}
\hline No. & $\begin{array}{l}\text { Variable } \\
\text { Name }\end{array}$ & $\begin{array}{l}\text { Definition } \\
\text { Conceptual }\end{array}$ & Indicators \\
\hline 1 & $\begin{array}{l}\text { Quality of } \\
\text { marketing } \\
\text { support }\end{array}$ & $\begin{array}{l}\text { Support provided by the } \\
\text { company in increasing } \\
\text { the quality of marketing } \\
\text { owned by salespeople }\end{array}$ & $\begin{array}{l}\text { - The company's ability to provide } \\
\text { motivation } \\
\text { - The company's ability to } \\
\text { supervise } \\
\text { - The ability of the company to } \\
\text { provide product information } \\
\text { - The ability of the company to } \\
\text { determine the remuneration } \\
\text { scheme } \\
\text { - The company's ability to } \\
\text { determine credit analysis policy }\end{array}$ \\
\hline 2 & $\begin{array}{l}\text { Quality sales } \\
\text { training }\end{array}$ & $\begin{array}{l}\text { Fundamentals that every } \\
\text { salesperson needs to }\end{array}$ & $\begin{array}{l}\text { - Market analysis training } \\
\text { - Communication training sells }\end{array}$ \\
\hline
\end{tabular}




\begin{tabular}{|c|c|c|c|}
\hline No. & $\begin{array}{c}\text { Variable } \\
\text { Name }\end{array}$ & $\begin{array}{l}\text { Definition } \\
\text { Conceptual }\end{array}$ & Indicators \\
\hline & & $\begin{array}{l}\text { follow, educate how to } \\
\text { improve performance, } \\
\text { have a sales strategy, } \\
\text { and have a responsibility } \\
\text { to fulfill the targets given } \\
\text { to each salesperson } \\
\text { more effectively and } \\
\text { efficiently }\end{array}$ & $\begin{array}{l}\text { - Completeness of the material } \\
\text { presented } \\
\text { - Accuracy of training methods }\end{array}$ \\
\hline 3 & $\begin{array}{l}\text { Salesforce } \\
\text { capability }\end{array}$ & $\begin{array}{l}\text { Includes expertise, } \\
\text { knowledge, values, } \\
\text { attitudes and personal } \\
\text { characteristics that } \\
\text { include the ability of } \\
\text { individuals in their work } \\
\text { to get the best results }\end{array}$ & $\begin{array}{l}\text { - Ability to master product } \\
\text { knowledge } \\
\text { - Accuracy determines the sales } \\
\text { segment } \\
\text { - Ability to manage the } \\
\text { presentation time effectively } \\
\text { - Ability to negotiate } \\
\text { - Ability to establish relationships } \\
\text { with customers }\end{array}$ \\
\hline 4 & $\begin{array}{l}\text { Salesperson's } \\
\text { Performance }\end{array}$ & $\begin{array}{l}\text { Salesperson's ability to } \\
\text { dominate the market, } \\
\text { cultivate opportunities, } \\
\text { and increase sales, to } \\
\text { achieve high corporate } \\
\text { profits }\end{array}$ & $\begin{array}{l}\text { - Increase sales growth } \\
\text { - Meet incoming application targets } \\
\text { - Meet sales targets }\end{array}$ \\
\hline
\end{tabular}

Source: Various journals

\section{RESEARCH METHOD}

\section{Primary Data}

Primary data is data taken directly from the source (Ghozali, 2011). In this study, the primary data is taken from credit card sales BNI channel Direct Sales Semarang and Yogyakarta. Required data are related to the performance of Sales Direct channel salespeople.

\section{Secondary Data}

Secondary data is data obtained indirectly from the source. In this study, secondary data collection through internal credit card management BNI Semarang and Yogyakarta in the form of credit card data from credit card sales BNI channel Direct Sales Semarang and Yogyakarta. 


\section{Data Retrieval Method}

In this study, researchers took the data through questionnaires containing questions with available answers. Researchers will submit a questionnaire to all sales credit card sales BNI channel Direct Sales Semarang and Yogyakarta in the area during monthly meetings so that answers obtained validly. The advantages of data collection methods through questionnaires are:

1. The result of this questionnaire is the primary data.

2. When the salesperson answers the question, has a free time and without the influence of others.

3. The selected answer is the aspiration of each salesperson.

4. Questions submitted together to facilitate analysis.

\section{Reliability Test and Validity}

Test Reliability test to test whether the questionnaire is still reliable to use, if the value of Cronbach alpha above 0.60 then reliable (Ferdinand, 2006), while the validity test is used to test whether the respondent understands the questionnaire created, if the total item correlation score above 0.4 then valid questioner (Ferdinand, 2006).

\section{Analysis Technique}

The technique of this research analysis utilizes structural equation modeling (SEM) technique, by testing whether the model described in this study is in accordance with the actual reality. The path diagram (path diagram) of this study can be described as: 
Figure 2

Diagram Path

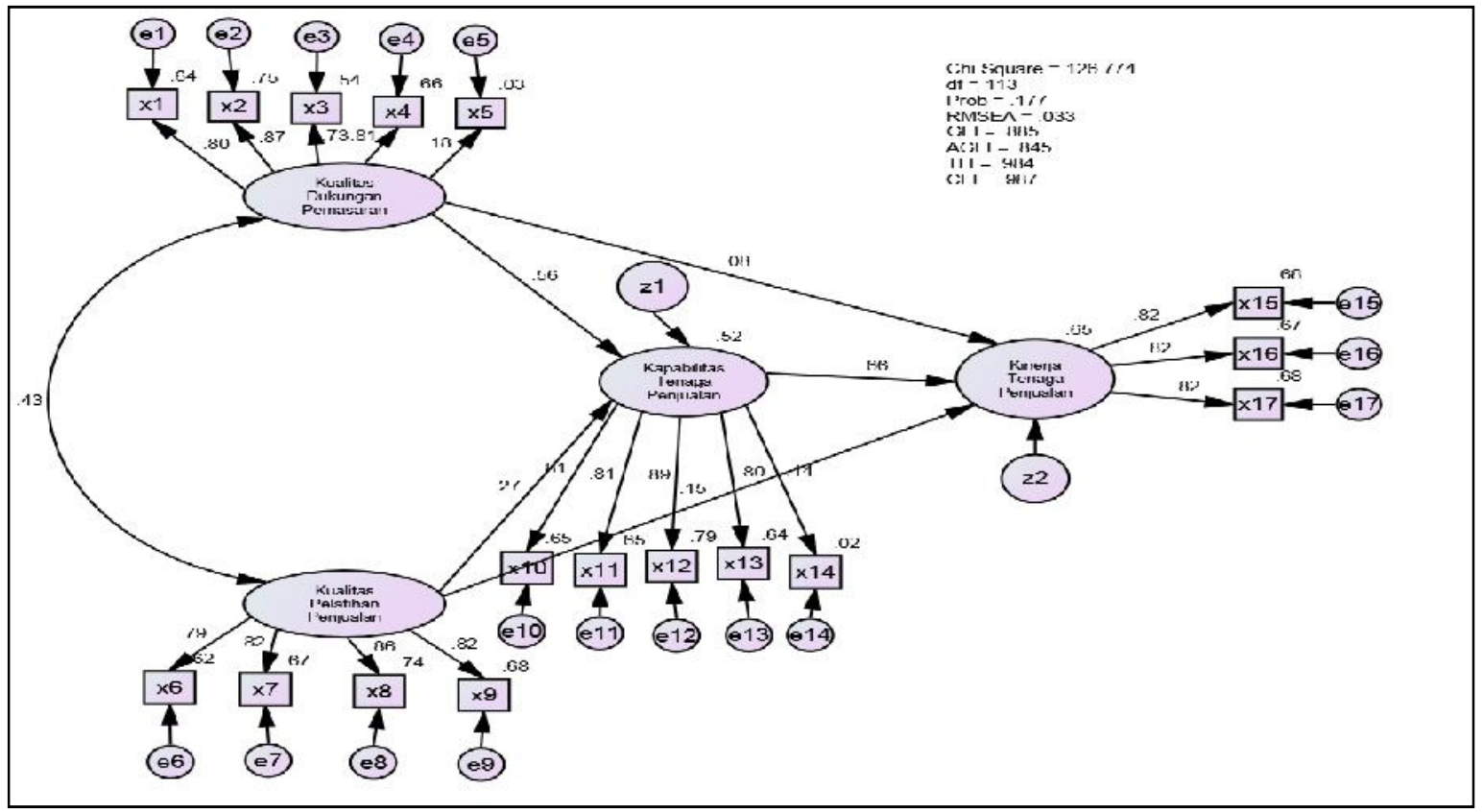

Based on the above path diagram, structural equation model can be constructed as described in the table below:

Table 3

\section{Structural Equation Model}

Salesperson Capability $=\gamma 1$ quality of marketing support $+\gamma 2$ quality of sales training + error Salesperson performance $=\gamma 3$ quality of marketing support $+\gamma 4$ sales training quality $+\gamma 5$ salesperson capability + error

The equation measurement model used for this study can be described in the table below:

Table 4

Measurement Model

\begin{tabular}{cl}
\hline \multicolumn{1}{c}{ Exogenous Concept } & \multicolumn{1}{c}{ Endogenous Concept } \\
\hline$X 1=\lambda 1$ quality of marketing support $+e 1$ & $X 10=\lambda 10$ salesperson capability $+e 10$ \\
$X 2=\lambda 2$ quality of marketing support $+e 2$ & $X 11=\lambda 11$ salesperson capability $+e 11$ \\
$X 3=\lambda 3$ quality of marketing support $+e 3$ & $X 12=\lambda 12$ seller capabilities $+e 12$ \\
$X 4=\lambda 4$ quality of marketing support $+e 4$ & $X 13=\lambda 13$ seller capability $+e 13$ \\
$X 5=\lambda 5$ quality of marketing support $+e 5$ & $X 14=\lambda 14$ seller capability $+e 14$ \\
$X 6=\lambda 6$ sales training quality $+e 6$ & $X 15=\lambda 15$ sales force performance $+e 15$ \\
$X 7=\lambda 7$ quality sales training $+e 7$ & $X 16=\lambda 16$ sales force performance $+e 16$ \\
$X 8=\lambda 8$ quality of sales training $+e 8$ & $X 17=\lambda 17$ performance of sales force $+e 17$ \\
$X 9=\lambda 9$ quality $+e 9$ & \\
\hline
\end{tabular}




\section{DATA ANALYSIS AND DISCUSSION}

Analysis of this research utilizes structural equation modeling (SEM) technique, by testing whether the model described in this study is in accordance with the actual reality. Previously will be done dimension test with confirmatory factor analysis. This model will also be analyzed and evaluated to determine the suitability of the proposed model. Furthermore, will be drawing conclusions based on the results of analysis of the study.

\section{Reliability Test and Validity}

Reliability testing in this study is intended to see whether there is a feasibility of a model, where a model is declared to have a feasibility if it has a value of Cronbach alpha above 0.6 . In the table below will explain the results of data processing.

Based on the results of reliability testing above, shows the value of Cronbach alpha of each variable has a value above 0.6 , then the statement in the questionnaire distributed to the respondent declared feasible. Testing the validity to see if the respondent understands the questionnaire made, if corrected item value of total correlation of each variable is $>0.4$ then the questionnaire declared valid or feasible to be examined.

Table 5

\section{Reliability Test}

\begin{tabular}{lc}
\hline \multicolumn{1}{c}{ Variable } & Cronbach Alpha \\
\hline Quality marketing support & 0,793 \\
Quality sales training & 0,829 \\
Salesperson capability & 0,827 \\
Performance of sales force & 0,821 \\
\hline
\end{tabular}

Table 6

Validity Test

\begin{tabular}{lc}
\hline \multicolumn{1}{c}{ Variable } & Corrected item-total correlation \\
\hline Quality marketing support & 0.768 \\
Quality sales training & 0,809 \\
Salesperson capability & 0,812 \\
Performance of sales force & 0,823 \\
\hline
\end{tabular}




\section{Research Data Analysis}

Analysis of research data in this study using AMOS software with SEM analysis techniques. SEM is an extension of structural equation modeling that tests whether the model is described in accordance with the actual reality, prior to SEM testing it is necessary to test the SEM assumptions first.

\section{Evaluation of Multicollinearity and Singularity}

Next will be test data to see multicollinearity and singularity in a combination of variables. The existence of the determinant value of the covariance matrix is the smallest or near zero as a hint of multicollinearity and singularity. Data processing yields a Determinant of sample covariance matrix of 15,015, far from zero. This means that in this study not found multicollinearity and singularity.

\section{Interpretation and modification of the model}

Interpretation and modification of the model into the final test phase in this study. After testing the model, it is expected that the residual result is small or close to zero. The frequency distribution of mandatory residual covariates has symmetric properties. Secure limit of the residual amount of $5 \%$, if more than $5 \%$ then the modification should be reviewed with a clear theoretical basis. To assess the significance of residuals generated by the model, it can use a Cut-off value of \pm 2.58 . In Table 4.8 will be shown data of standardized residual covariances processed using AMOS program.

\section{Structural Equation Modeling Analysis}

Structural Equation Model (SEM) can be utilized to test complicated model, which in this research use intervening variable. In addition, SEM can also be used to test whether the model is described in accordance with the actual reality or not.

This research is analyzed by using Structural Equation Model (SEM) full model. After analyzing the unidimensionality of latent variables formers tested by confirmatory factor analysis.

Further tests of conformity and statistics can be done to analyze the results of the full model. Figure 3 shows the results of data processing analysis Structural Equation Model (SEM) full mode. In table will also be described the test results of conformity and statistics of this model. 
Figure 3

Test result Structural Equation Model (SEM)

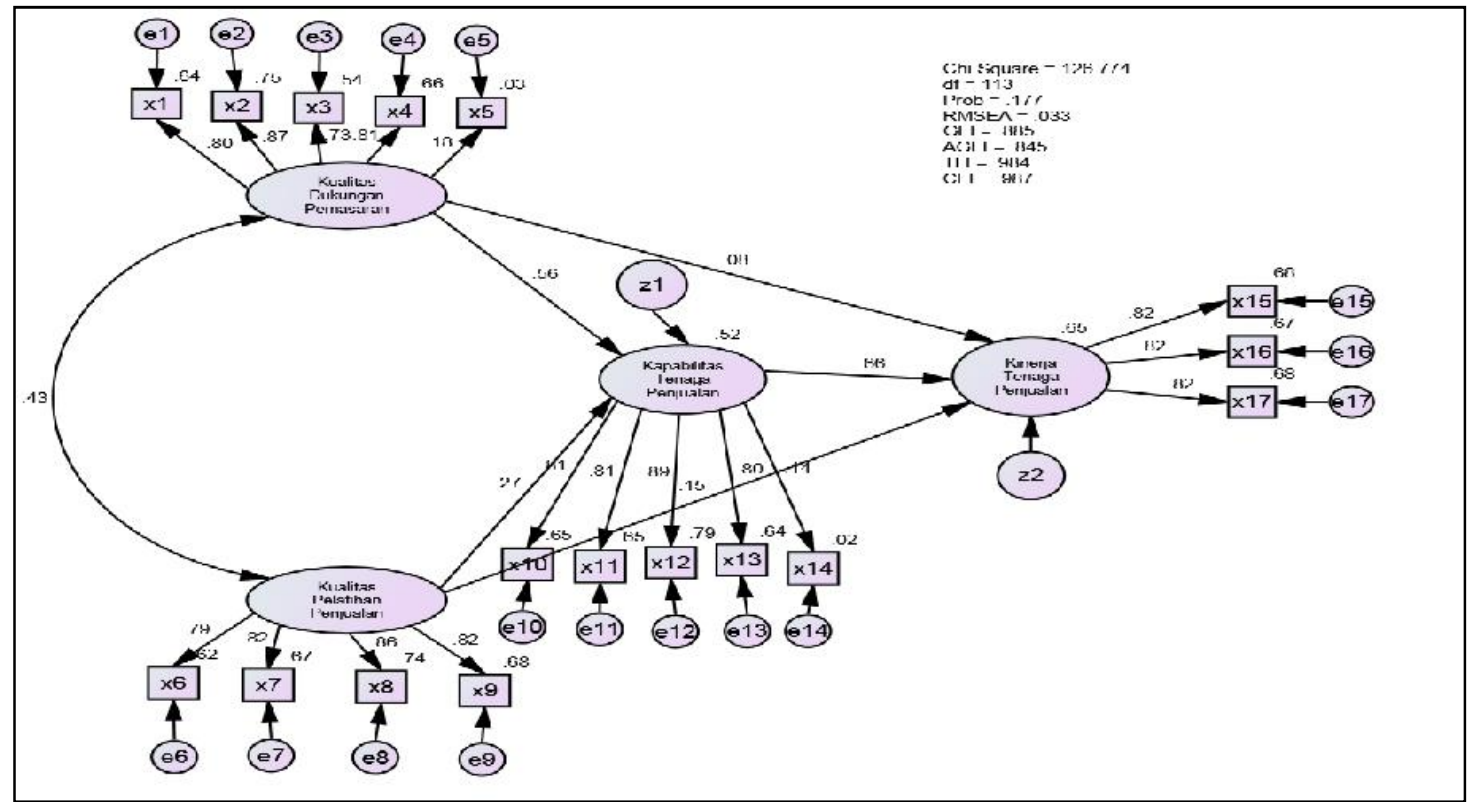

A hypothesis test is done to test whether the model used is appropriate and feasible with research data or not. The results of the feasibility test of the research model can be seen in Table 7 below.

Table 7

Model Feasibility Test Result Structural Equation Model (SEM)

\begin{tabular}{lccc}
\hline Goodness of Fit Indeks & Cut-off Value & Result of Model & Evaluasi Model \\
\hline Chi-Square & Small $(<189.539)$ & 126,774 & Good \\
Probability & $\geq 0.05$ & 0,177 & Good \\
RMSEA & $\leq 0.08$ & 0,033 & Good \\
GFI & $\geq 0.90$ & 0,885 & Marginal \\
AGFI & $\geq 0.90$ & 0,845 & Marginal \\
TLI & $\geq 0.95$ & 0,984 & Good \\
CFI & $\geq 0.95$ & 0,987 & Good \\
\hline
\end{tabular}

Source: Research data is processed

As a basis for analyzing the research hypothesis required a statistical test to measure the relationship between variables. In this research, statistical test using SEM is needed to see the relationship between variables with the indicated value of Probability (p) and Critical Ratio (CR) of each relationship between variables. Table 8 shows the process of statistical testing. 
Table 8

Standardized Regression Weight

\begin{tabular}{|c|c|c|c|c|c|c|}
\hline & & & Estimate & S.E. & C.R. & $P$ \\
\hline Copability_Power_Sales & $<---$ & Quality_Support_Marketing & .583 & .111 & 5.234 & \\
\hline Copability_Power_Sales & $<---$ & Quality_Training_Sales & 285 & .099 & 2.884 & .004 \\
\hline Perfomance_Power_Sales & $<--$ & Copability_Power_Sales & .666 & .137 & 4.861 & \\
\hline Perfomance_Power_Sales & $<--$ & Quality_Support_Marketing & .086 & .041 & 2.098 & .048 \\
\hline Perfomance_Power_Sales & $<---$ & Quality_Training_Sales & .161 & .068 & 2.368 & .029 \\
\hline$x 1$ & $<--$ & Quality_Support_Marketing & 1.000 & & & \\
\hline$x 9$ & $<--$ & Quality_Training_Sales & 1.000 & & & \\
\hline$x 13$ & $<--$ & Copability_Power_Sales & 1.000 & & & \\
\hline$x 12$ & $<--$ & Copability_Power_Sales & 1.043 & .099 & 10.513 & *** \\
\hline$x 11$ & $<--$ & Copability_Power_Sales & .995 & .107 & 9.298 & *** \\
\hline$x 10$ & $<--$ & Copability_Power_Sales & 1.023 & .110 & 9.336 & *** \\
\hline$x 15$ & $<--$ & Perfomance_Power_Sales & 1.000 & & & \\
\hline$x 16$ & $<---$ & Perfomance_Power_Sales & .918 & .097 & 9.418 & *** \\
\hline$x 17$ & $<--$ & Perfomance_Power_Sales & 1.050 & .111 & 9.466 & $\star \star \star *$ \\
\hline$x 6$ & $<--$ & Quality_Training_Sales & .959 & .105 & 9.165 & *** \\
\hline$x 7$ & $<---$ & Quality_Training_Sales & 1.053 & .109 & 9.664 & *** \\
\hline$x 8$ & $<--$ & Quality_Training_Sales & 1.051 & .102 & 10.263 & *** \\
\hline$x 4$ & $<---$ & Quality_Support_Marketing & .973 & .107 & 9.131 & *** \\
\hline$x 5$ & $<--$ & Quality_Support_Marketing & .212 & .117 & 1.806 & .071 \\
\hline$x 14$ & & Copability_Power_Sales & .136 & .094 & 1.444 & .149 \\
\hline$x 2$ & $<---$ & Quality_Support_Marketing & 1.071 & .109 & 9.846 & $* * \star$ \\
\hline$x 3$ & & Quality_Support_Marketing & .908 & .113 & 8.052 & $x x^{\prime \prime}$ \\
\hline
\end{tabular}

\section{Direct Effect and Indirect Effect}

Relationships between variables need to be analyzed to see if those variables have direct or no influence on other variables. The results of the analysis can then generate an interpretation for the selection of appropriate strategies for research.

Based on existing theories and previous research results, the quality of marketing support and the quality of sales training will have a direct or indirect effect on salesperson performance. The indirect influence of the salesperson's performance is by first through the capability of the sales force, which in turn produces an influence on the salesperson's performance. In Table 9 we will explain the results of the direct impact test. For indirect effect test results will be described in Table 10. 
Table 9

Direct Effect

\begin{tabular}{llcll}
\hline & $\begin{array}{l}\text { Quality__ } \\
\text { Training_- } \\
\text { Sales }\end{array}$ & $\begin{array}{l}\text { Quality__ } \\
\text { Support_ } \\
\text { Marketing }\end{array}$ & $\begin{array}{l}\text { Capabilities_ } \\
\text { Power_ } \\
\text { Sales }\end{array}$ & $\begin{array}{l}\text { Performance } \\
\text {-Power_ } \\
\text { Sales }\end{array}$ \\
\hline $\begin{array}{l}\text { Capabilities_ } \\
\text { Power_Sales }\end{array}$ & .274 & .563 & .000 & .000 \\
$\begin{array}{l}\text { Performance- } \\
\text { Power_Sales }\end{array}$ & .153 & .082 & .658 & .000 \\
\hline
\end{tabular}

Table 10

Indirect Effect

\begin{tabular}{|c|c|c|c|c|}
\hline & $\begin{array}{l}\text { Quality } \\
\text { Training } \\
\text { Sales }\end{array}$ & $\begin{array}{l}\text { Quality_- } \\
\text { Support_- } \\
\text { Marketing }\end{array}$ & $\begin{array}{l}\text { Capabilities_ } \\
\text { Power_- } \\
\text { Sales }\end{array}$ & $\begin{array}{l}\text { Performance- } \\
\text { Power_- } \\
\text { Sales }\end{array}$ \\
\hline $\begin{array}{l}\text { Capabilities } \\
\text { Power_Sales }\end{array}$ & .000 & .000 & .000 & .000 \\
\hline $\begin{array}{l}\text { Performance- } \\
\text { Power_Sales }\end{array}$ & 180 & .371 & .000 & .000 \\
\hline
\end{tabular}

The calculation of the direct and indirect effects of the salesperson's experience, the quality of marketing support and the quality of the sales training on the salesperson's performance, results in a comparison that leads to a greater direct impact of the quality of marketing support and the quality of sales training on salesperson performance. The effect of the quality of marketing support on the performance of the sales force directly resulted in the figure of 0.082 . The calculation indirectly yields the number 0.371 . This means the capability of salespeople can be a liaison between the quality of marketing support to salesperson performance.

The effect of the quality of sales training on salesperson performance directly resulted in the number of 0.153 . The calculation indirectly yields a figure of 0.180 . This means that sales force capability can be a liaison between the quality of sales training on salesperson performance.

\section{Hypothesis Testing}

Further testing hypotheses will be executed as described in the previous chapter. In table 11 below the hypothesis test will be based on the CR value of a causal relationship resulting from the processing of Structural Equation Model (SEM). 
Table 11

Regression Weight Structural Equational Model

\begin{tabular}{|c|c|c|c|c|c|c|}
\hline & & & Estimate & S.E. & C.R & $P$ \\
\hline $\begin{array}{l}\text { Capabilities_Power_ } \\
\text { Sales }\end{array}$ & & $\begin{array}{l}\text { Quality_Support_ } \\
\text { Marketing }\end{array}$ & .583 & .111 & 5.234 & *** \\
\hline $\begin{array}{l}\text { Capabilities_Power_ } \\
\text { Sales }\end{array}$ & $<--$ & $\begin{array}{l}\text { Quality_Trainning_ } \\
\text { Sales }\end{array}$ & .285 & .099 & 2.884 & .004 \\
\hline $\begin{array}{l}\text { Performance } \\
\text { Power_Sales }\end{array}$ & & $\begin{array}{l}\text { Capabilities_Power_ } \\
\text { Sales }\end{array}$ & .666 & .137 & 4.861 & *** \\
\hline $\begin{array}{l}\text { Performance } \\
\text { Power_Sales }\end{array}$ & $<-$ & $\begin{array}{l}\text { Quality_Support_ } \\
\text { Marketing }\end{array}$ & .086 & .041 & 2.098 & .048 \\
\hline $\begin{array}{l}\text { Performance_ } \\
\text { Power_Sales }\end{array}$ & & $\begin{array}{l}\text { Quality_Trainning_ } \\
\text { Sales }\end{array}$ & .161 & .068 & 2.368 & .029 \\
\hline
\end{tabular}

\section{Interpretation of Results}

The result of analysis from Critical Ratio (CR) quality of marketing support variable to sales force capability gets number 5,234 . The probability value $=0,000$ $<0.05$, which means the quality of marketing support has an influence on the capability of the sales force. The results show that $\mathrm{H} 1$ is accepted.

The result of analysis of Critical Ratio (CR) variable of quality of marketing support to the performance of salesman gets number 2,098. Probability value $=$ $0.048<0.05$, which means the quality of marketing support has an influence on the performance of salespeople. The results show that $\mathrm{H} 2$ is accepted.

The result of analysis from Critical Ratio $(\mathrm{CR})$ variable of sales training quality to sales force capability gets number 2,884 . Probability value $=0.004$ $<0.05$, which means the quality of sales training has an influence on the capability of salespeople. The results show that $\mathrm{H} 3$ is accepted.

The result of analysis of Critical Ratio (CR) of sales quality training variable to salesman performance gets the figure of 2,368. Probability value $=0.048<0.05$, which means the quality of sales training has an influence on the performance of salespeople. The results show that $\mathrm{H} 4$ is accepted.

The result of analysis from Critical Ratio $(\mathrm{CR})$ variable of sales force capability to salesperson performance get figure 4,861 . Probability value $=0,000$ $<0.05$, which means sales force capability has an influence on the performance of salespeople. The results show that $\mathrm{H} 5$ is accepted.

\section{Discussion}

The results stated that the quality of marketing support higher than $\mathrm{BNI}$ able to increase the capability of the sales force. High-quality marketing support can 
improve the capability of salespeople. A salesperson with marketing support will provide sales force capability tall one. Likewise, the company is expected through the quality of marketing support will result in better capability.

The results stated that the quality of marketing support higher than BNI able to improve the performance of sales force. High-quality marketing support can improve the performance of salespeople. A salesperson with the support of marketing will provide good performance for the company. Sales with good corporate support to the market can improve the performance of its salespeople.

The results stated that the quality of good sales training from BNI will increase the capability of the sales force. More training will increase the capability of the sales force. Training can improve the skills of the sales force resulting in sales force capability.

The results stated that the quality of good sales training from BNI will result in high sales force performance. More training will improve the performance of salespeople. Salespeople have a big role in the sales process. Starting from introducing the product to the market, negotiation, and closing. With the capability of the high sales force, the product will be more easily marketed. The capability of the sales force should always be supported by the company. This is done to improve the capability and capability of the sales force.

The result shows that higher capability of BNI's sales force can improve the performance of sales force. The capability of salespeople from salespeople can be seen from the ability of salespeople to negotiate, make plans, and master the product well can indicate the capability of salespeople. With frequent salespeople planning visits, presentations, and acquisitions directly will further hone the capabilities of salespeople. This will result in improved sales force performance.

\section{CONCLUSIONS AND IMPLICATIONS}

\section{Conclusions}

The analysis and discussion that has been presented in the previous chapter resulted in several conclusions as follows:

1. The result of analysis of Critical Ratio $(\mathrm{CR})$ variable of quality of marketing support to sales force capability indicates the quality of marketing support that influences sales force capability. The results show that $\mathrm{H} 1$ is accepted.

2. The analysis of Critical Ratio (CR) of the quality of marketing support to the performance of salespeople shows the quality of marketing support that influences the salesperson's performance. The results show that $\mathrm{H} 2$ is accepted. 
3. The result of analysis from Critical Ratio (CR) variable of sales training quality to sales force capability indicates the quality of sales training which influence sales force capability. The results show that $\mathrm{H} 3$ is accepted.

4. The result of analysis from Critical Ratio (CR) variable of sales training quality to the performance of the power shows the quality of sales training which influence the performance of the salesman. The results show that $\mathrm{H} 4$ is accepted.

5. From the calculation results obtained from the CR of the sales force capability of the salesperson's performance shows the sales force capability that influences the salesperson's performance. The results show that $\mathrm{H} 5$ is accepted

\section{Conclusion on Research Problems}

This study aims to obtain solutions related problems that occur in the marketing of Credit Cards in BNI is a problem in this study, namely "how to improve sales force performance?".

The conclusion of this research has given the answer of the problem briefly that can give influence in improving the performance of sales force, among others: first, the capability of salespeople can affect salesperson performance by looking at the quality of marketing support; second, the capability of salespeople can affect salesperson performance by looking at the quality of sales training.

\section{Theoretical Implications}

The theoretical implications of this study are as follows: The performance of salespeople is strongly influenced by the capabilities of salespeople (Verbeke et al., 2008), while sales force capabilities are influenced by the quality of marketing support (Kairisto-Mertanen et al., 2013) and the quality of sales training (Asiegbu et al., 2012). The results of this study confirm the results of previous studies conducted by Verbeke et al., (2008); Franke and Park (2006); Kairisto-Mertanen et al., (2013); and Asiegbu et al., (2012) which gives results that the quality of marketing support and the quality of sales training affect the capability of the sales force, and the capability of the sales force affects the performance of the sales force. 
Table 12

Theoritical Implications

\begin{tabular}{|c|c|c|}
\hline Previous Research & Research Now & Theoretical Implications \\
\hline $\begin{array}{l}\text { Verbeke et al., (2008) in his } \\
\text { research states that sales } \\
\text { force capability has a } \\
\text { significant influence on } \\
\text { salesperson }\end{array}$ & $\begin{array}{l}\text { performance Salesforce } \\
\text { capability has a significant } \\
\text { positive influence on } \\
\text { salesperson performance }\end{array}$ & $\begin{array}{l}\text { This study strengthens } \\
\text { research study Verbeke et } \\
\text { al., (2008) sales force } \\
\text { capability has a significant } \\
\text { influence on salesperson } \\
\text { performance }\end{array}$ \\
\hline $\begin{array}{l}\text { Kairisto-Mertanen et al., } \\
(2013) \text { in his research } \\
\text { stated that the quality of } \\
\text { marketing support has a } \\
\text { significant influence on the } \\
\text { capability of salespeople }\end{array}$ & $\begin{array}{l}\text { The quality of marketing } \\
\text { support has a significant } \\
\text { positive effect on the } \\
\text { capability of the sales } \\
\text { force. }\end{array}$ & $\begin{array}{l}\text { This study reinforces the } \\
\text { research study Kairisto- } \\
\text { Mertanen et al., (2013) } \\
\text { which states that the } \\
\text { quality of marketing } \\
\text { support has a significant } \\
\text { effect on the capability of } \\
\text { salespeople }\end{array}$ \\
\hline $\begin{array}{l}\text { Asiegbu et al., (2012) in his } \\
\text { research stated that the } \\
\text { quality of sales training has } \\
\text { a significant influence on } \\
\text { the capability of the sales } \\
\text { force }\end{array}$ & $\begin{array}{l}\text { The quality of sales training } \\
\text { has a significant positive } \\
\text { effect on sales force } \\
\text { capability }\end{array}$ & $\begin{array}{l}\text { This study strengthens } \\
\text { research study Asiegbu et } \\
\text { al. (2012) that the quality of } \\
\text { sales training has a } \\
\text { significant influence on the } \\
\text { capability of the sales force }\end{array}$ \\
\hline
\end{tabular}

\section{Managerial Implications}

Open questions in this research questionnaire have provided some positive suggestions for $\mathrm{BNI}$ management, as follows:

1. $\mathrm{BNI}$ is expected to more often provide training related to product knowledge with equipped sales tools such as credit card dummy, presentation module that contains $\mathrm{BNI}$ credit card products in detail and complete, and updated list of promo-promo is running. This is a provision of the sales force in the process of acquiring credit card BNI.

2. BNI expected to provide more soft skill training such as public speaking, negotiation skills, and presentation so that every salesperson can have good selling ability.

3. BNI expected more brainstorming to know the latest issues, ideas, and input from Direct Sales so that things that are happening in the field can always be updated with every Direct Sales Credit Card BNI.

$\mathrm{BNI}$ is expected to invite Direct Sales more frequently to be able to maintain good relations with Card Holder, maintaining its BNI Credit Card (after sales) so that Direct Sales can have a wider relationship and will more easily get customer reference. 
4. BNI is expected to always create positive things to Direct Sales and provide something more for Card Holder in terms of service and gimmick. This can create a positive word of mouth from Card Holder, so it will further simplify Direct Sales to make BNI Credit Card Acquisition.

\section{Limitations of Research}

In this research there are some limitations that arise, namely:

1. The result of squared multiple correlations yields the number of 0,52 for sales force capability variable; the figure of 0.65 for salesperson performance. The optimal magnitude should be at least 0.70 . This indicates that the antecedent variable is less optimal for the endogenous variables.

2. The object of this study is credit card sales BNI channel Direct Sales Semarang and Yogyakarta, so the results of this study cannot be generalized in absolute terms against other objects with the same case.

\section{Future Research Agenda}

The results of this study can be used as a source of ideas for further research. The limitations that arise can be an evaluation of future research. Another variable is needed to extend the research.

\section{REFERENCES}

Ahmad, SZ; Basir M Sah; dan Kitchen PJ, (2010), "The relationship between sales skills and salesperson performance, and the impact of organizational commitment as a moderator: an empirical study in a Malaysian Telecommunication Company," International Journal of Economics and Management

Asiegbu, Ikechukwu; Ogbuji Chinedu; Vincent Ubani, (2012), "Salesforce competence management," European Journal of Bussiness and management

Aynur, Akata, dan Ayse Akyol, (2008), "Increasing competitive performance of small and medium-sized enterprises: A market orientation approach for success," Harvard Bussiness Review

Bielecki, Andre; Albers Sonke; dan Mantrala Murali, (2012), "Salesperson efficiency benchmarking using sales response data," Department of Innovation

Cooper, D.R dan Emory, C.W (1995), Bussiness Research Methods, Fifth 
Edition, USA: Richard D. Irwin, Inc.

Denny Hotman Hasiholan Sitompul, (2004), "Pengaruh Orientasi Belajar dan Komitmen Organisasional Terhadap Keja Cerdas Dalam Meningkatkan Kinerja Penjualan," Jurnal Sains Pemasaran Indonesia, Vol.III, No.1, Mei 2004, 41-54

Ferdinand, Augusty Tae, (2000), Structural Equation Modelling Dalam Penelitian Manajemen, Badan Penerbit Universitas Diponegoro Semarang.

Gasperz, V. (1997), Manajemen Kualitas: Penerapan Konsep-Konsep Kualitas dalam Manajemen Bisnis Total, Penerbit PT Gramedia Pustaka Utama, Jakarta.

Hair, J.F.,Jr.,R.E. Anderson, R.L., Tatham \& W.C. Black, (1995), Multivariate Data Analysis With Readings, Englewood Cliffs, NJ: Prentice Hall.

Kairisto-Mertanen, Lisa; Harri Terho; Danny Belenger; dan Wesley Johnston, (2013), "Salesperson goal orientation and the selling performance relationship," Journal Bussiness Marketing Management

Kotler, Philip, (1997), Marketing Management: Analysis, Planning, Implementation, and Control, $9^{\text {th }}$ Ed., Englewood Cliffs, NJ: Prentice Hall, Inc.

Pettijohn, Charles E; Linda S Pettijohn; AJ Taylor; Bruce D Keillor, (2010),"Adaptive selling and sales performance," The Journal of Applied Bussiness Research

Porter, M (1993), Competitive Advantage, The Free Press: New York.

PT Bank Negara Indonesia (Persero). Tbk. (2017), BNI Forum

Rehme, Sarina; dan Carsten Rennhak, (2011), "Marketing and sales - successful peacekeeping," ESB Bussiness School

Seong Kok Kim dan Ji Sook Hong, (2005), "The relationship between salesperson competencies and performance in the Korean pharmaceutical industry," Management Revue

Skinner, Steven J, (2000), "Peak Performance in The Salesforce", Journal of Personal Selling \& Sales Management, Vol XX, No.1.

Slater, S.F \& Narver, J.C, (1994), "Market Orientation and The Learning Organization," Journal of Marketing, Vol.59, July

Smith, Brent A, (2004), "Relationship management in the sales organizations," Departments of Marketing 
Suff, Paul dan Peter Reilly, (2012), "Selling rewards paying for performance in your sales force," Institute for Employment Studies

Sujan, Harish, Barton A. Weitz, dan Nirmalya Kumar, (1994), "Learning Orientation, Working Smart, and Effective Selling", Journal of Marketing, Vol.58, July, 39-52.

Tansu, AB, (1999), "Benchmark of Successful Salesforce Performance," Canadian Journal of Administrative Science

Verbeke, Willem J; Frank D Belschak; Arnold B Baker; Bart Dietz, (2008), "When intelligence (Dys) functional for achieving sales performance," Journal of Marketing 